\title{
Medical Students' Perception of Educational Environment and Effect of COVID-19 Pandemic on Learning
}

\author{
Tehmina P Syed ${ }^{1}$, Samar Faheem², Shabnum Hassan ${ }^{3}$
}

\begin{abstract}
Aim and background: The educational environment of students plays a vital role in their well-being and academic performance. Evaluating it is of crucial concern while looking for areas of improvement. The Dundee Ready Educational Environmental Measure (DREEM) is one of the most suitable tools to evaluate the educational environment for health training settings. The coronavirus disease-2019 (COVID-19) pandemic has made online teaching commonplace and changed how traditional medical education is imparted, making the assessment of students' perception of the environment especially necessary.

Materials and methods: Final year medical students in Hamdard University were given a questionnaire to fill after an exam, which included the DREEM survey and open-ended feedback and suggestion questions about their experience learning during the COVID-19 pandemic. For the DREEM survey, the positive Likert scale items were scored from 0 to 4, and the negative items were scored in reverse. The data were analyzed using SPSS 26.0 software. For the analysis of open-ended responses, common themes were identified and grouped.

Results: A total of 93 completed questionnaires were received. The mean total DREEM score was calculated as $119.85 \pm 37.86$. It was more positive than negative but had a high standard deviation. Student's perception of teachers scored the lowest, with a mean percentage of $55.25 \%$. Student's academic self-perceptions scored the highest with $65.06 \%$. The open-ended responses were grouped into five themes, with only nine students saying their online learning experience was positive.

Conclusion: This study revealed that most students of Hamdard University scored their educational environment positively but do not enjoy online classes. For the future, medical schools need to improve the teacher-student interaction and have a more empathetic approach toward students. Medical schools also need to work on a more engaging teaching style, which includes adapting new methods for online teaching. Keywords: Coronavirus disease-2019 pandemic, Dundee Ready Education Environment Measure survey, Educational environment, Learning, Medical students.

Journal of Medical Academics (2021): 10.5005/jp-journals-10070-0068
\end{abstract}

\section{INTRODUCTION}

The educational environment plays an important part in the academic success and personal development of students. For medical students, the environment includes the classroom, lecture halls, and clinical settings. Students need to be able to feel safe, respected, and motivated in their environments. ${ }^{1}$ They need to have a comfortable learning space, a sense of belonging, and factors in the environment that contribute to their self-confidence.

The Dundee Ready Education Environment Measure (DREEM) is most commonly used with undergraduate students in medical schools. ${ }^{2}$ It has been used in 20 different countries and its validity has been established in Pakistan. ${ }^{3}$ It is a 50 -item questionnaire that analyses five aspects of student's perceptions using a Likert scale: Student's perception of learning/teaching (I) with 12 items, Student's perceptions of teachers (II) with 11 items, Student's academic self-perceptions (III) with 8 items, Student's perception of the atmosphere (IV) with 12 items, and Student's social selfperceptions (V) with 7 items.

Because of the drastic change in teaching and classroom environments during the coronavirus disease-2019 (COVID-19) pandemic, there was a need to assess the effects of the change on students and gauge their opinion to identify areas of improvement.

The primary objective of this study was to evaluate medical student's perceptions of their educational environment at Hamdard University and to identify aspects of the environment that work and ones that need improvement. The secondary objective of this study was to find out how the pandemic and lockdown affected the learning of the students.
1,3 Department of Obstetrics and Gynecology, Hamdard University Hospital, Karachi, Pakistan

${ }^{2}$ Dow University of Health Sciences, Karachi, Pakistan

Corresponding Author: Tehmina P Syed, Department of Obstetrics and Gynecology, Hamdard University Hospital, Karachi, Pakistan, Phone: +923314138682, e-mail: tehmina.jawwad@yahoo.com

How to cite this article: Syed TP, Faheem S, Hassan S. Medical Students' Perception of Educational Environment and Effect of COVID-19 Pandemic on Learning. J Med Acad 2021;4(1):11-15.

Source of support: Nil

Conflict of interest: None

\section{Study Design}

This was a cross-sectional survey administered to final (5th) year students of MBBS in Hamdard University in March 2021.

\section{Materials and Methods}

Students were administered this survey after their gyne exam was held in March. This period was chosen as it was one of the few times all students were present on campus after the COVID-19 lockdown. Different groups had exams on three different days. Verbal consent of the students was taken with the option given to opt-out. No teacher was present in the room while the students filled out the survey, and all surveys were anonymous with no identifiable information. Along with the 50 -item DREEM survey, students were

() The Author(s). 2021 Open Access This article is distributed under the terms of the Creative Commons Attribution 4.0 International License (https://creativecommons. org/licenses/by-nc/4.0/), which permits unrestricted use, distribution, and non-commercial reproduction in any medium, provided you give appropriate credit to the original author(s) and the source, provide a link to the Creative Commons license, and indicate if changes were made. The Creative Commons Public Domain Dedication waiver (http://creativecommons.org/publicdomain/zero/1.0/) applies to the data made available in this article, unless otherwise stated. 
asked for their feedback and suggestions about learning during the COVID-19 pandemic.

\section{Statistical Analysis}

SPSS Software 26 and Microsoft Excel were used to analyze the data. Forty-one positive items were scored as follows: "0" for Strongly Disagree, "1" for Disagree, "2" for Neutral, " 3 " for Agree and "4" for Strongly Agree. 9 negative items (Items 4, 8, 9, 17, 25, 35, 39, 48, $50)$ were scored in the reverse order, i.e., " 4 " for Strongly Disagree, "3" for Disagree, "2" for Neutral, "1" for Agree and "0" for Strongly Agree. Total DREEM score was calculated. Total subscale score was also calculated. Mean and standard deviation were used to analyze the data. Percentages were calculated from the mean. The scores were interpreted using the guide provided by McAleer and Roff. ${ }^{4}$

For the qualitative analysis, five themes were identified among the students who responded: students who talked about psychological stress, students who complained about a lack of clinical exposure, students who did not like online learning, students who talked about exams, and students who preferred online learning.

\section{Results}

A total of 93 students completed the questionnaires. The mean, standard deviation, and percentages of the total and subscale score are given in Table 1. The mean DREEM score was found to be $119.8 / 200$. The means of all subscales were more positive than negative (i.e., above 50\%). The lowest score was of student's perceptions of teachers at 24.31/44 (55.25\%) and the highest was student's academic self-perceptions with a score of 20.82/32
(65.06\%). The means of individual DREEM items organized according to subscale are shown in Table 2 and items requiring attention are shown in Table 3.

For the open-ended section, the majority of responses talked negatively about the online learning experience. There were complaints of Internet issues and the teaching style not being the same. Students wanted more interactive lectures, and more lectures in general even if they were online. Seven students also talked about psychological stress and a lack of counseling services. Several students wanted gaps in their exam dates, and "expected the exam to be more relaxed because of COVID". Seventeen students talked about facing a lack of clinical exposure. Surprisingly, nine students talked about a positive experience with online learning (Figs 1 and 2).

\section{Discussion}

A positive, encouraging educational environment is the foundation that paves the way for the success of a student in the university. Medical universities have to focus on the professional and personal development of the student. It is important to get the feedback of the student body about the environment they interact with instead of solely relying on the teacher's perceptions. ${ }^{5}$

The mean DREEM score of students in our study was slightly higher (119.98 compared with 116.65) than fifth-year medical students of Aga Khan University, a private medical school in Karachi. ${ }^{6}$ However, the standard deviation for the mean scores in our study was also higher (SD = 37.86 compared with 16.97). Subscale scores for both medical colleges were similar, but our study had a higher standard deviation for all of them. This suggests there

Table 1: Mean, standard deviation, and percentage of total DREEM score and subscales $(N=93)$

\begin{tabular}{lcccc}
\hline & Mean & Standard deviation & Mean scored out of & Percentage \\
\hline Student's perception of learning/teaching & 28.18 & 9.96 & 48.00 & 58.70 \\
Student's perceptions of teachers & 24.31 & 5.52 & 44.00 & 55.25 \\
Student's academic self-perceptions & 20.82 & 9.06 & 32.00 & 65.06 \\
Student's perception of atmosphere & 29.48 & 10.15 & 48.00 & 61.41 \\
Student's social self-perceptions & 17.05 & 5.36 & 28.00 & 60.89 \\
Total DREEM score & 119.85 & 37.86 & 200.00 & 58.92 \\
\hline
\end{tabular}

Table 2: DREEM items ${ }^{\mathrm{a}}$

\begin{tabular}{|c|c|c|}
\hline \multirow{2}{*}{\multicolumn{2}{|c|}{ Students' perceptions of learning-12 items }} & \multirow[t]{2}{*}{ Mean } \\
\hline & & \\
\hline \multicolumn{2}{|c|}{ I am encouraged to participate in class } & 2.35 \\
\hline \multicolumn{2}{|c|}{ The teaching is often stimulating } & 2.37 \\
\hline \multicolumn{2}{|c|}{ The teaching is student-centered } & 2.63 \\
\hline \multicolumn{2}{|r|}{ The teaching helps to develop my competence } & 2.59 \\
\hline \multicolumn{2}{|c|}{ The teaching is well focused } & 2.57 \\
\hline \multicolumn{2}{|r|}{ I feel I am being well prepared for my career } & 2.73 \\
\hline \multicolumn{2}{|c|}{ The teaching time is put to good use } & 2.67 \\
\hline \multicolumn{2}{|r|}{ The teaching overemphasizes factual learning } & 1.30 \\
\hline \multicolumn{2}{|r|}{ I am clear about the learning objectives of this course } & 2.45 \\
\hline \multicolumn{2}{|r|}{ The teaching encourages me to be an active learner } & 2.59 \\
\hline \multicolumn{2}{|r|}{ Long-term learning is emphasized over short-term learning } & 2.49 \\
\hline \multicolumn{2}{|c|}{ The teaching is too teacher-centered } & 1.47 \\
\hline \multicolumn{3}{|c|}{ Students' perceptions of teachers- 11 items } \\
\hline \multirow{2}{*}{\multicolumn{2}{|c|}{ The teachers are knowledgeable }} & 2.59 \\
\hline & & \\
\hline 12 & Journal of Medical Academics, Volume 4 Issue 1 (January-June 2021) & \\
\hline
\end{tabular}


Contd...

The teachers deliver research-led teaching $\quad 2.34$

$\begin{array}{lr}\text { The teachers ridicule the students } & 1.90\end{array}$

$\begin{array}{lr}\text { The teachers are authoritarian } & 1.48\end{array}$

The teachers help me to develop my practical skills 2.56

$\begin{array}{ll}\text { The teachers are good at providing feedback to students } & 2.57\end{array}$

$\begin{array}{ll}\text { The teachers provide constructive criticism here } & 2.48\end{array}$

$\begin{array}{ll}\text { The teachers give clear examples } & 2.61\end{array}$

$\begin{array}{lr}\text { The teachers get angry in class } & 1.58\end{array}$

The teachers are well prepared for their classes $\quad 2.62$

I feel able to ask the questions I want 2.66

Students' academic self-perceptions-8 items

Learning strategies that worked for me continue to work for me now $\quad 2.39$

I am confident about passing this year $\quad 2.62$

$\begin{array}{ll}\text { The teaching helps to develop my confidence } & 2.69\end{array}$

$\begin{array}{ll}\text { Last year's work has been good preparation for this year's work } & 2.68\end{array}$

I am able to memorize all I need $\quad 2.53$

I have learned a lot about the way scientific research is carried out $\quad 2.65$

$\begin{array}{ll}\text { My problem-solving skills are being well developed here } & 2.59\end{array}$

Much of what I have to learn seems relevant to a career in biological sciences 2.63

Students' perceptions of atmosphere-12 items

The atmosphere is relaxed during laboratory/practical/fieldwork classes 2.58

$\begin{array}{ll}\text { This course is well timetabled } & 2.52\end{array}$

$\begin{array}{ll}\text { Cheating is a problem in this faculty } & 1.66\end{array}$

$\begin{array}{ll}\text { The atmosphere is relaxed during lectures } & 2.69\end{array}$

There are opportunities for me to develop my interpersonal skills $\quad 2.70$

$\begin{array}{ll}\text { I feel comfortable in class socially } & 2.57\end{array}$

The atmosphere is relaxed during seminars/tutorials $\quad 2.52$

$\begin{array}{ll}\text { The atmosphere motivates me as a learner } & 2.65\end{array}$

$\begin{array}{ll}\text { I find the experience disappointing } & 1.68\end{array}$

I am able to concentrate well $\quad 2.62$

$\begin{array}{ll}\text { The enjoyment outweighs the stress of the course } & 2.66\end{array}$

$\begin{array}{ll}\text { The students irritate the teachers } & 1.56\end{array}$

Students' social self-perceptions-7 items

$\begin{array}{ll}\text { There is a good support system for students who get stressed } & 2.44\end{array}$

$\begin{array}{ll}\text { I am too tired to enjoy this course } & 1.81\end{array}$

$\begin{array}{ll}\text { I am rarely bored during this course } & 2.60\end{array}$

$\begin{array}{lr}\text { I have good friends on this faculty } & 2.47\end{array}$

$\begin{array}{lr}\text { My social life is good } & 2.69\end{array}$

$\begin{array}{lr}\text { I seldom feel lonely } & 2.47\end{array}$

$\begin{array}{ll}\text { My accommodation is pleasant } & 2.57\end{array}$

${ }^{a}$ Negatively worded items require rescoring

is a varying difference in experience for the students at Hamdard University.

Our study also found students of Hamdard had lower DREEM scores compared with a medical college in Lahore with a mean score of $121.70 .^{7}$ Students in Lahore had a better perception of teachers but rated their atmosphere and social self-perception lower than students in our study.
While most students in our study rated their education environment positively, the score was not excellent and more improvement is needed in some areas, specifically, student's perception of teaching, and of teachers themselves.

A study done in Australia found that most students experienced "humiliating and intimidating behaviors" by teachers during clinical rotations, including aggressive questioning. ${ }^{8}$ Another study by Rautio, et al., done in Finland found humiliation was the most 
common form of student mistreatment. ${ }^{9}$ Rautio et al. suggest that these attitudes have been passed down from teacher to student, and student's future attitudes as doctors are formed in these years

Table 3: Items requiring attention (mean $<2)$

I am too tired to enjoy this course
The teachers ridicule the students
The teachers are authoritarian
Cheating is a problem in this faculty
I find the experience disappointing
The teachers get angry in class
The students irritate the teachers
The teaching overemphasizes factual learning
The teaching is too teacher-centered

and are influenced by the treatment they receive by their teachers and other members of the hospital staff.

There is a need to address the low score of student's perceptions of teachers to raise more empathetic doctors, both with their patients and with their juniors. Specific areas of improvement need to be identified and teachers and staff who interact directly with students should be given the training to focus on improving student-teacher relationships.

In students' perceptions of learning, students reported that teachers overemphasized factual learning and the teaching was too teacher-centered. Other studies have pointed out this problem with factual learning, ${ }^{10}$ which emphasizes surface-level learning. The curriculum and examination style of medical schools must stress the importance of a deeper understanding of how things work, and students' evaluations should reflect their concepts. The teaching style needs to see a shift to becoming more student-centered,

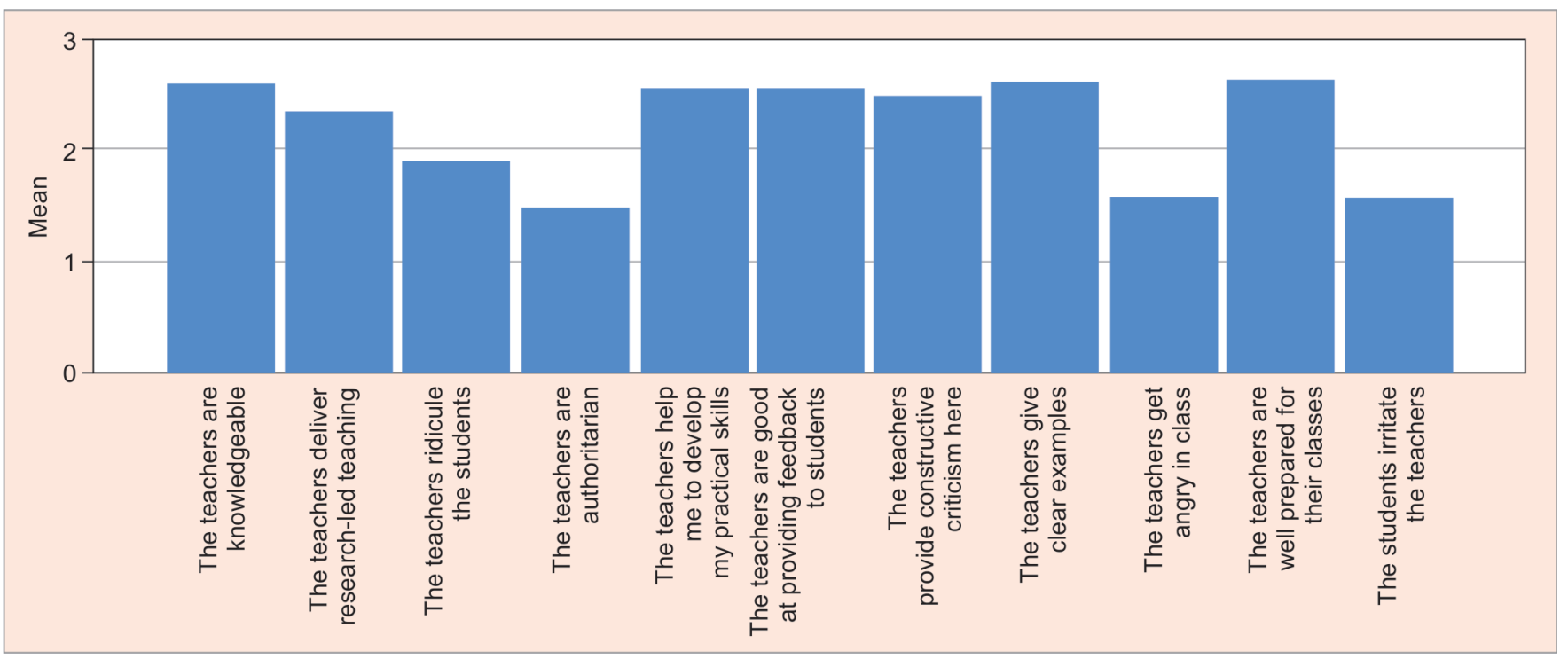

Fig. 1: Mean of items in Students' perception of teachers $(N=93)$

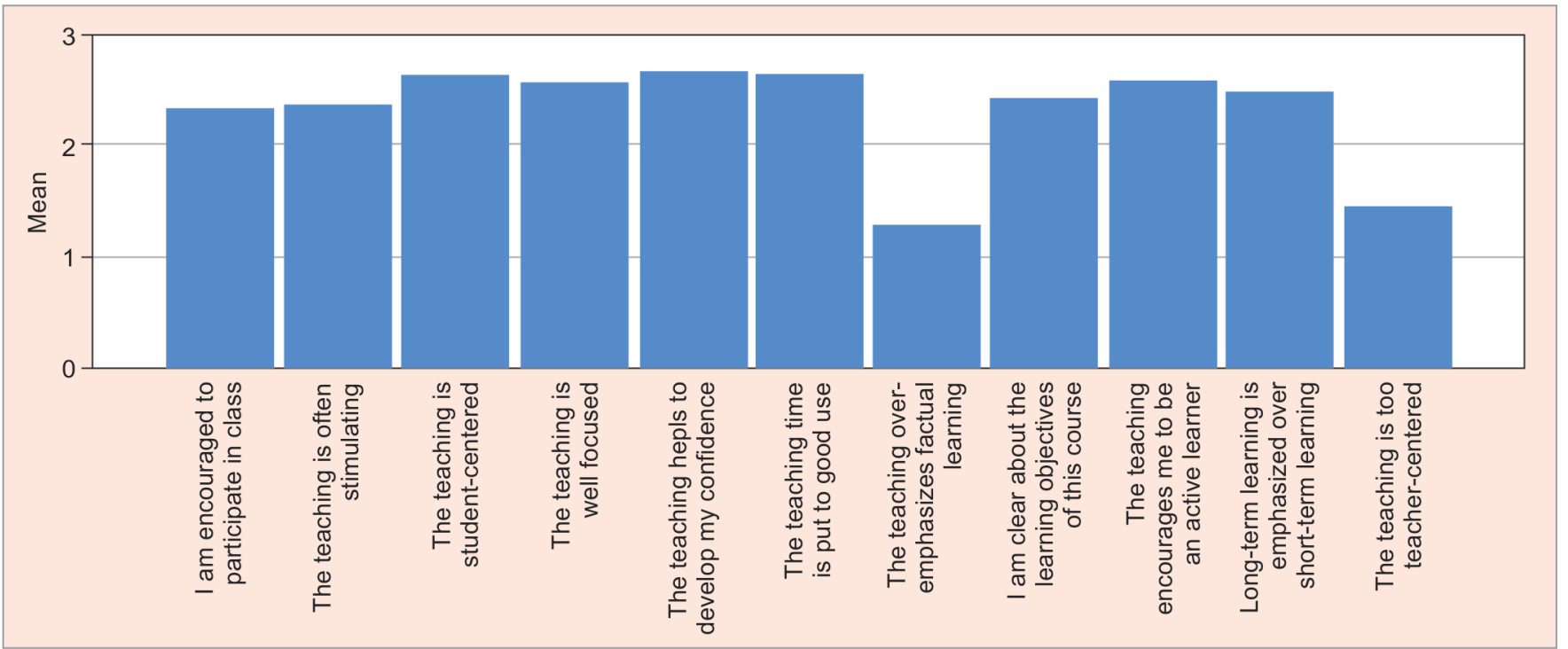

Fig. 2: Mean of items in Students' perception of teaching $(N=93)$ 
with students taking an active role in the classroom, through class participation, projects, and presentations.

Regarding students' perception of the atmosphere, the items that need attention include "cheating", "the students' irritating the teacher", and "I find the experience disappointing". This shows the medical school needs to do a better job of keeping the decorum within the classroom and ensuring the atmosphere for other students is not disruptive.

The most difficult part of online learning for medical school is including clinical experience. While no solution will replace the in-hospital, face-to-face patient interaction, there are ways to bridge the gap through technology. Many doctors have incorporated zoom clinics during the pandemic, and students can observe or take histories virtually. Simulated clinical experiences through software can be used to enhance students' learning, as it is being used in other parts of the world. ${ }^{11}$

It is now apparent that online learning and the virtual classroom will become a constant part of the learning environment. Teachers too must adapt and gain the necessary skills needed to educate students online. Especially for medical education, the classroom must be interactive and encourage student participation. This can be done by holding smaller online sessions and face-to-face lectures to promote discussion. An article by Jiang et al. contains tips to teach medical students online, compiled from 40 Chinese medical schools' reports after they were forced to switch to online classrooms. ${ }^{12}$ Medical schools and teachers should use this as a guide going forward.

\section{LiMITATIONS}

The study did not have another group to compare the scores with (e.g., students from another batch). It cannot be accurately compared with past studies done before the COVID pandemic, which has changed the dynamics of the medical learning environment.

\section{ConCLUSION}

Students score their educational environment positively, but the scores are not excellent. There is a need for improvement in some areas, especially in the teaching style and virtual classrooms. A positive student-teacher relationship needs to be emphasized as well. More studies need to be done in other medical universities to understand the attitude of students about their environment in the wake of the pandemic.

\section{References}

1. Hutchinson L. Educational environment. BMJ 2003;326(7393):810812. DOI: $10.1136 / \mathrm{bmj} .326 .7393 .810$.

2. Miles S, Swift L, Leinster SJ. The dundee ready education environment measure (DREEM): a review of its adoption and use. Med Teach 2012;34(9):e620-e634. DOI: 10.3109/0142159X.2012.668625.

3. Khan JS, Tabasum S, Yousafzai UK, et al. DREEM on: validation of the dundee ready education environment measure in Pakistan. J Pak Med Assoc 2011;61(9):885-888.

4. Roff S, McAleer S, Harden RM, et al. Development and validation of the dundee ready education environment measure (DREEM). Med Teach 1997;19(4):295-299. DOI: 10.3109/01421599709034208.

5. Genn JM, Harden RM. What is medical education here really like? Suggestions for action research studies of climates of medical education environments. Med Teach 1986;8(2):111-124. DOI: 10.3109/01421598609010737.

6. Rehman R, Ghias K, Fatima SS, et al. Dream of a conducive learning environment: one DREEM for all medical students!. J Pak Med Assoc 2017;67(1):7-11.

7. Zafar U, Daud S, Shakoor Q, et al. Medical students' perceptions of their learning environment at Lahore Medical and Dental College Lahore. J Ayub Med Coll Abbottabad 2017;29(4):595-598.

8. Scott KM, Caldwell PH, Barnes EH, et al. Teaching by humiliation" and mistreatment of medical students in clinical rotations: a pilot study. Med J Aust 2015;203(4):185e.1-185e.6. DOI: 10.5694/mja15.00189.

9. Rautio A, Sunnari V, Nuutinen M, et al. Mistreatment of university students most common during medical studies. BMC Med Educ 2005;5(1):36. DOI: 10.1186/1472-6920-5-36.

10. Vaughan B, Carter A, Macfarlane C, et al. The DREEM, part 1: measurement of the educational environment in an osteopathy teaching program. BMC Med Educ 2014;14(1):99. DOI: 10.1186/14726920-14-99.

11. Tabatabai S. COVID-19 impact and virtual medical education.J Adv Med Educ Prof 2020;8(3):140-143. DOI: 10.30476/jamp.2020.86070.1213.

12. Jiang $\mathrm{Z}, \mathrm{Wu} \mathrm{H}, \mathrm{Cheng} \mathrm{H}$, et al. Twelve tips for teaching medical students online under COVID-19. Med Educ Online 2021;26(1):1854066. DOI: 10.1080/10872981.2020.1854066. 